\title{
Hill Cutting in Sylhet City: A Case Study
}

\author{
Muradul Islam ${ }^{1}$, Md Mustafizur Rahman ${ }^{2}$, Saddam Hussain Mubin $^{3}$ \\ ${ }^{1}$ Department of Civil Engineering, Leading University, Bangladesh \\ ${ }^{2}$ Department of Civil Engineering, Leading University, Bangladesh \\ ${ }^{3}$ Department of Civil Engineering, Leading University, Bangladesh
}

\begin{abstract}
Indiscriminate hill cutting is one of the major environmental problem in Sylhet city. As this city has many hills and hillocks (Tilas), its environment is closely related with hills. So massive indiscriminate hill cutting can create environmental problems. Sylhet is an Earthquake prone area of Bangladesh and it is situated in the most risky zone of seismic map of the country. This paper is an investigation of Indiscriminate cutting of hills in Sylhet city. The main causes of hill cutting, public perception of the people living on hilly areas about hill cutting, awareness level of them are the main focus point of this paper. We also tried to find out the awareness level condition of people buying plots from the housing companies in hilly areas.
\end{abstract}

Keywords: Hill Cutting, Hills and Hillocks, Sylhet City, Hill Cutting awareness.

\section{INTRODUCTION}

Destruction of hills and hillocks is increasing with time in Sylhet city and the city is becoming more vulnerable to natural calamities. Hill cutting causing deforestation and with cutting of hills people are disturbing the natural eco-system of the hilly areas. Mostly for unplanned urbanization this hill cutting is going on and some other causes are also behind it. In this paper we focused on these points to know the actual scenario of hill cutting of the city. We worked with four major hill cutting areas. These are West Pirmahalla, TV Gate, Halder Para of Ward 7, 21 and 8 respectively.

\section{Study Area}

Sylhet is the fifth largest city of Bangladesh and it is situated in the north eastern side of the country with a population of more than 663,198 .[1] The city is located at $24.8917^{\circ} \mathrm{N} 91.8833^{\circ} \mathrm{E}$ with 27 wards and 210 Mahallas. It is a small city with an area of $26.50 \mathrm{~km}^{2}$. Geographically this city is on the most earthquake prone zone in Bangladesh. It is on the zone-1 of updated seismic map developed by Bangladesh National Building Code(BNBC 1993).[2] Among all the areas of Bangladesh greater Sylhet region, north-east of capital Dhaka is the most earthquake prone area .[3]

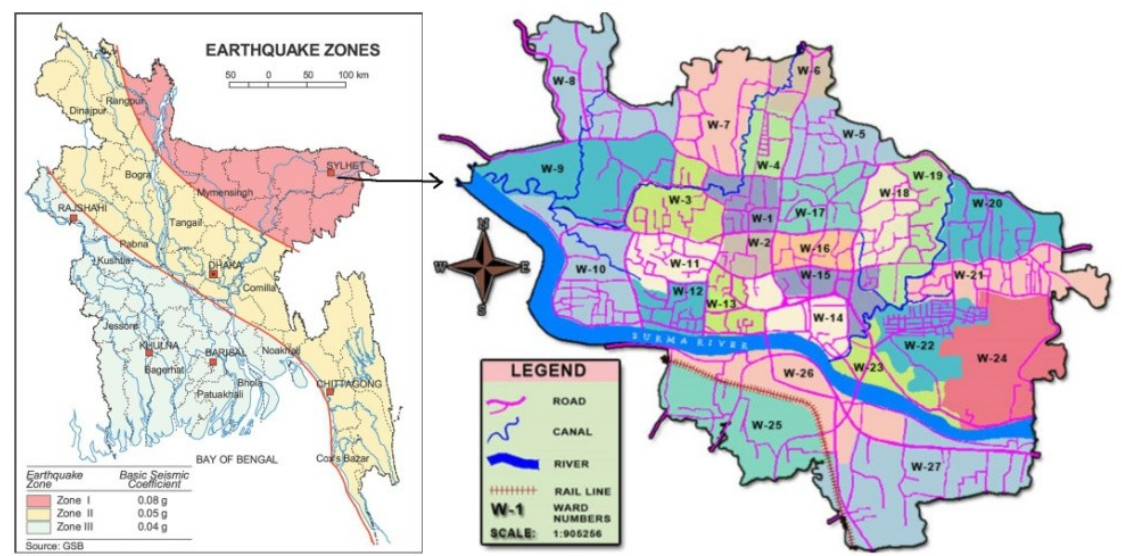

Sylhet is a land of hot, wet and humid tropical climate.[4] The temperature data from 1971 to 2000 and Annual rainfall data of Sylhet city from 1957 to 2002 is given below for easy understanding of the climate of Sylhet city. The data is collected from BMD.

Table-1 : Maximum and Minimum Temperature data of Sylhet city

\begin{tabular}{|l|l|l|}
\hline Year & Maximum Temperature & Minimum Winter Temperature \\
\hline $1971-1980$ & 36.6 & 9.7 \\
\hline $1981-1990$ & 37.3 & 6.4 \\
\hline $1991-2000$ & 38.8 & 6.9 \\
\hline
\end{tabular}


Table-2: Annual Rainfall data of Sylhet city

\begin{tabular}{|l|l|}
\hline Year & Annual Rainfall $(\mathrm{mm})$ \\
\hline $1957-1977$ & 4177.1 \\
\hline $1981-1991$ & 3880.0 \\
\hline $1992-2002$ & 3856.2 \\
\hline
\end{tabular}

\section{Findings from earlier studies}

Bangladesh hills are basically composed of unconsolidated sedimentary rocks such as sandstone, siltstone, shale and conglomerate. Unsustainable lands use and alteration in the hills including indiscriminate deforestation and hill cutting are two major factors in Bangladesh that aggravated the landslide vulnerability in the hilly areas. [5] In a research paper about Destroying hills in the northeastern part of Bangladesh Islam, Hasan and Chowdhury discussed about some causes of hill cutting and they stated that "The law permits cutting or razing of hills with permission and fee. However, it is not clearly defined under what circumstances it will be permitted, but put in the hand of a committee. The above ruling thus makes scope for corruption. [6] On the $27^{\text {th }}$ issue of The Daily Star's weekly Law and Rights Supplement Barrister M. Omar Bin Harun Khan discussed about this law briefly. From that we came to know that actually the law is clearly defined after what circumstances hill cutting will be permitted.As per section $3 \mathrm{C}$ of the Act no person shall without the previous sanction of the authorized officer cut or raze any hill. As per this section no such sanction shall be granted unless the authorised officer or such other authority as the government may specify is satisfied that-

(a) The cutting or razing of the hill shall not cause any serious damage to any hill, building, structure or land adjacent to or in the vicinity of the hill, or

(b) The cutting or razing of the hill shall not cause any silting of or obstruction to any drain, stream or river, or

(c) The cutting or razing of the hill is necessary in order to prevent loss of life or property, or

(d) The cutting of the hill is such as is normally necessary for construction of dwelling house without causing any major damage to the hill, or

(e) The cutting or razing of the hill is necessary in the public interest.

Rule 27 states that in addition to the fees, designs as required under the Rules, the applicant must also submit the following documents:

(a) Clearance or NOC from the environment department;

(b) Topographical or contour map of the hill;

(c) Detailed design showing all the necessary development plan, protective measures etc.

The Building Constriction Act was enacted in 1952, which was given effect from 21.03.1953, with a view to preventing haphazard erection of buildings, excavation of tanks and cutting of hills and hillocks in Bangladesh. Initially the Act did not contain any specific provision for the cutting of hills. But later on after realizing the momentous of this issue, the government amended the 1952 Act twice in 1987 and in 1990. In the Building Construction (Amendment) Act of 1990, amongst other, section 3C and 3D were inserted into the 1952 Act. [8]

\section{Materials and Method}

In this study at first, we measured the destroyed hill areas of last 12 years using Google map and earth point on the three big hill cutting zones of Sylhet city. There are some major hill cutting areas on ward 7, 8, 20 and 21. We calculated total destroyed hill areas of the sites from Ward-7, Ward-21, and Ward-8 respectively.

Table-3: Destroyed hills on last 12 years in ward 7, 21 and 8

\begin{tabular}{|c|c|c|c|c|c|c|c|}
\hline Name & Location & $\begin{array}{l}\text { Number } \\
\text { of Points }\end{array}$ & $\begin{array}{l}\text { Area } \\
\text { (Hectares) }\end{array}$ & $\begin{array}{l}\text { Perimeter/Length } \\
\text { (Miles) }\end{array}$ & $\begin{array}{l}\text { Centroid/Mid- } \\
\text { Point } \\
\text { (Degrees) }\end{array}$ & $\begin{array}{l}\text { Bounding Box } \\
\text { Maximum } \\
\text { (Degrees) }\end{array}$ & $\begin{array}{l}\text { Bounding Box } \\
\text { Minimum } \\
\text { (Degrees) }\end{array}$ \\
\hline site 1 & $\begin{array}{l}\text { West } \\
\text { p.mollah }\end{array}$ & 28 & $\begin{array}{l}8.02810006 \\
040642\end{array}$ & $\begin{array}{l}0.6813376520598 \\
81\end{array}$ & $\begin{array}{l}24.9207556^{\circ}, \\
091.8681620\end{array}$ & $\begin{array}{l}24.9219616^{\circ}, \\
091.8698822^{\circ}\end{array}$ & $\begin{array}{l}24.9196863^{\circ}, \\
091.8663219^{\circ}\end{array}$ \\
\hline site2 & Tv gate & 23 & $\begin{array}{l}7.53888815 \\
854309\end{array}$ & $\begin{array}{l}0.6608250320059 \\
99\end{array}$ & $\begin{array}{l}24.9082869^{\circ}, \\
091.8882267^{\circ}\end{array}$ & $\begin{array}{l}24.9094021^{\circ}, \\
091.8903258^{\circ}\end{array}$ & $\begin{array}{l}24.9071823^{\circ}, \\
091.8862173^{\circ}\end{array}$ \\
\hline site3-1 & $\begin{array}{l}\text { Halder } \\
\text { para }\end{array}$ & 5 & 0.158 & 0.1052 & $\begin{array}{l}24.9268147^{\circ}, \\
091.8425869^{\circ}\end{array}$ & $\begin{array}{l}24.9270753^{\circ} \\
091.8428483^{\circ}\end{array}$ & $\begin{array}{l}24.9265780^{\circ}, \\
091.8422557^{\circ}\end{array}$ \\
\hline sit3-2 & $\begin{array}{l}\text { Halder } \\
\text { para }\end{array}$ & 10 & 0.5024 & 0.2057 & $\begin{array}{l}24.9286689^{\circ} \\
091.8499682^{\circ}\end{array}$ & $\begin{array}{l}24.9293740^{\circ}, \\
091.8503750^{\circ}\end{array}$ & $\begin{array}{l}24.9281717^{\circ}, \\
091.8497305^{\circ}\end{array}$ \\
\hline
\end{tabular}

Some pictures of previous and current condition of these sites: 


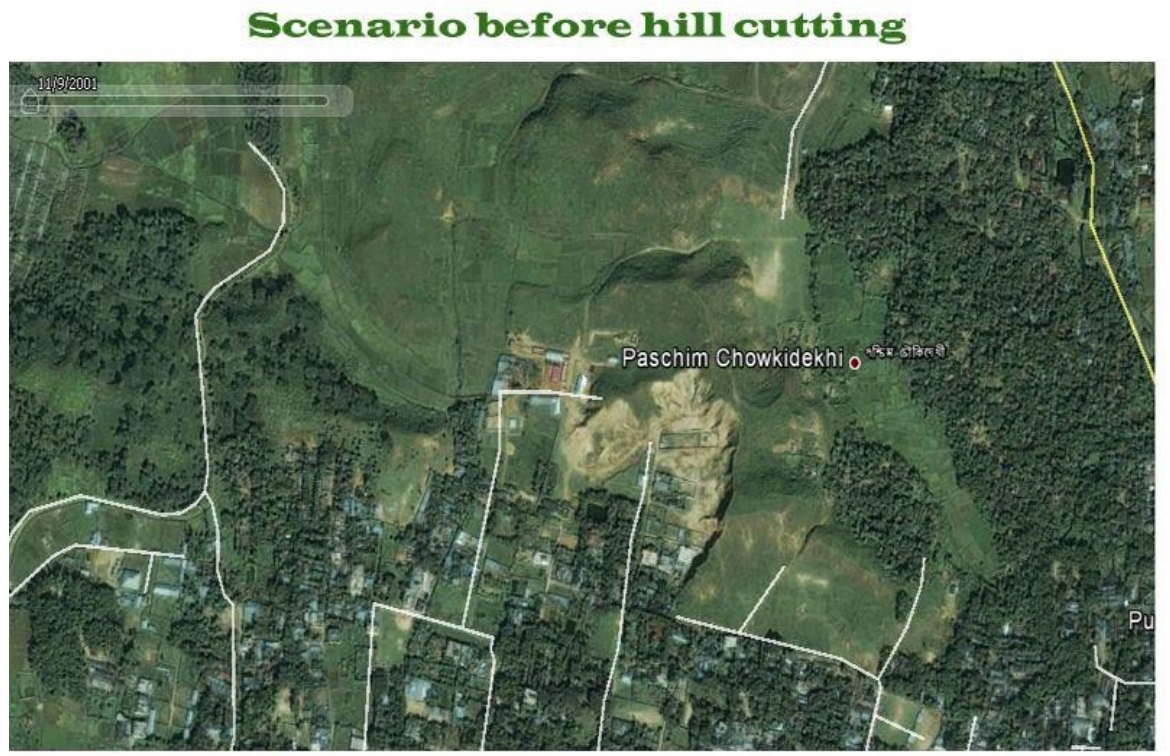

Scenario before hill cutting

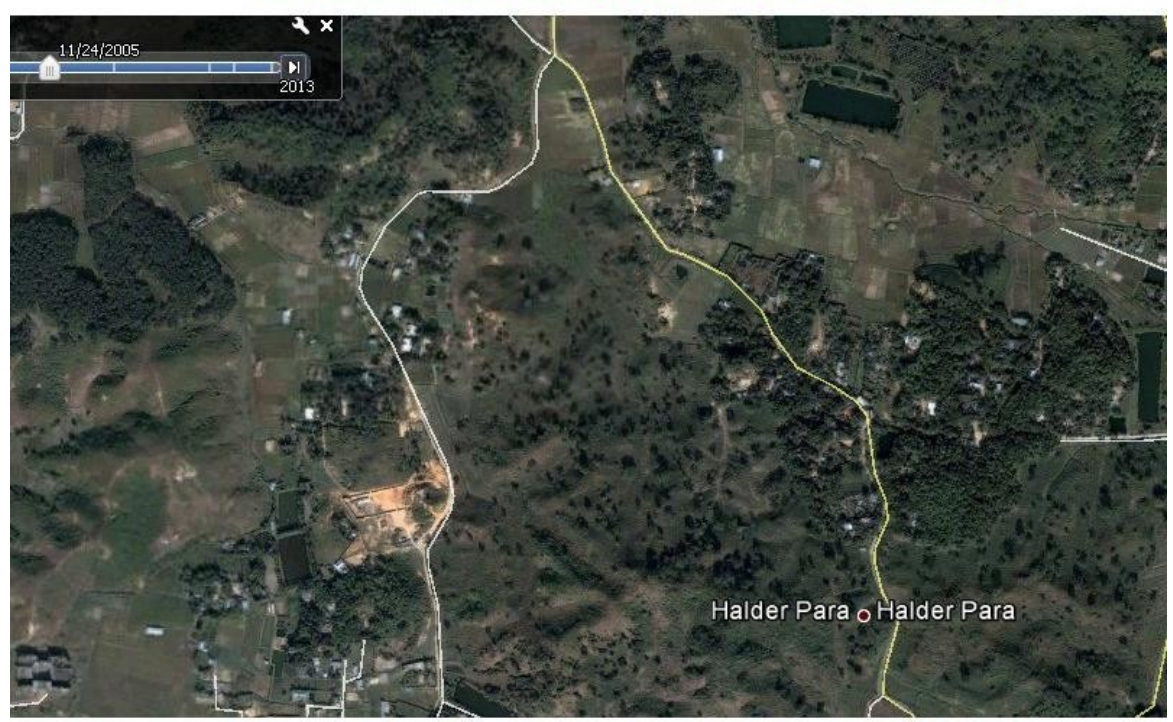

Scenario before hill cutting

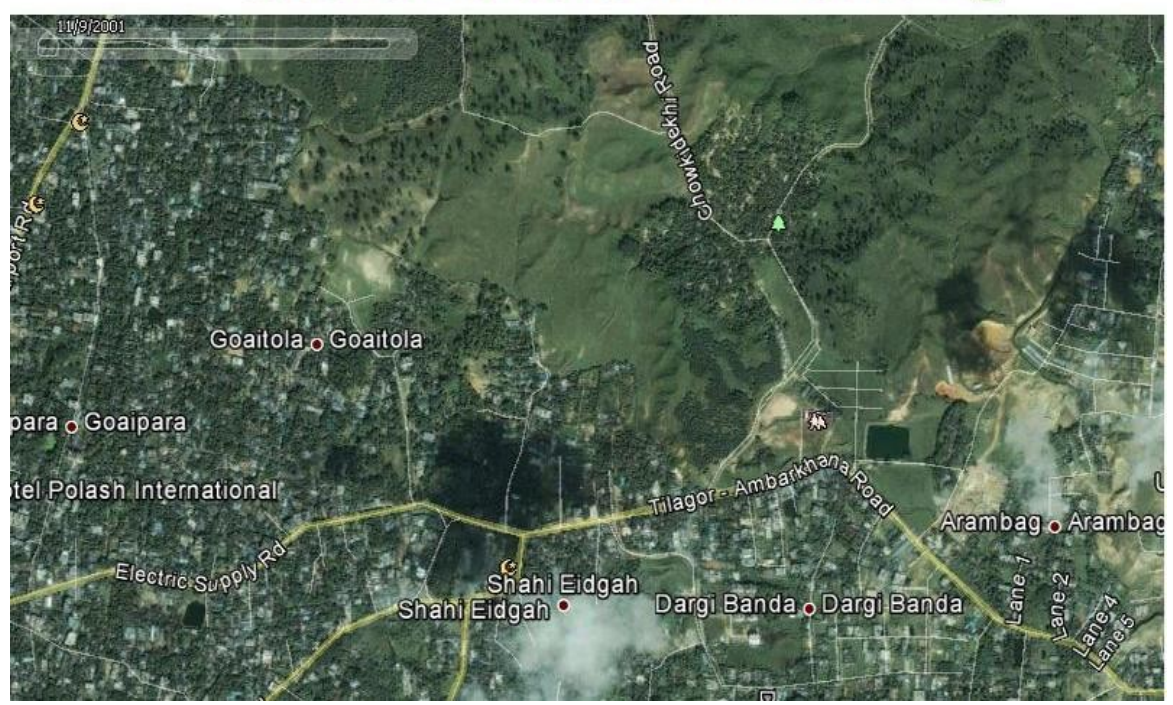

Figure 1 Before hill cutting started rapidly 


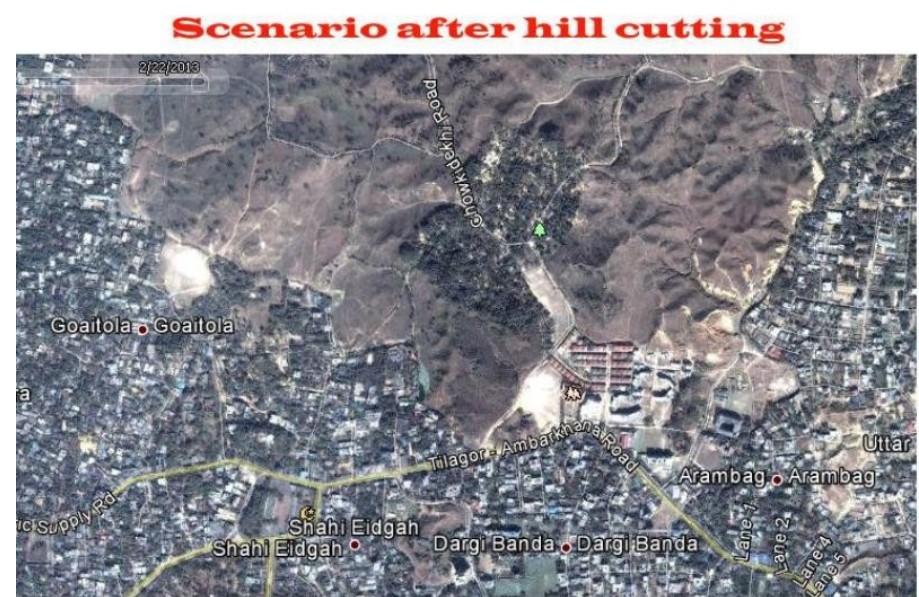

Scenario after hill cutting

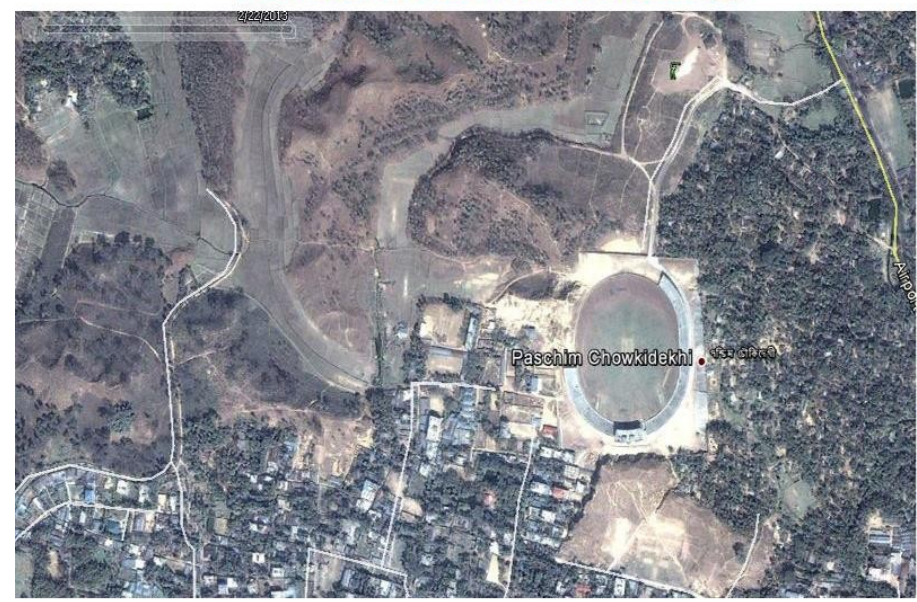

Scenario after hill cutting

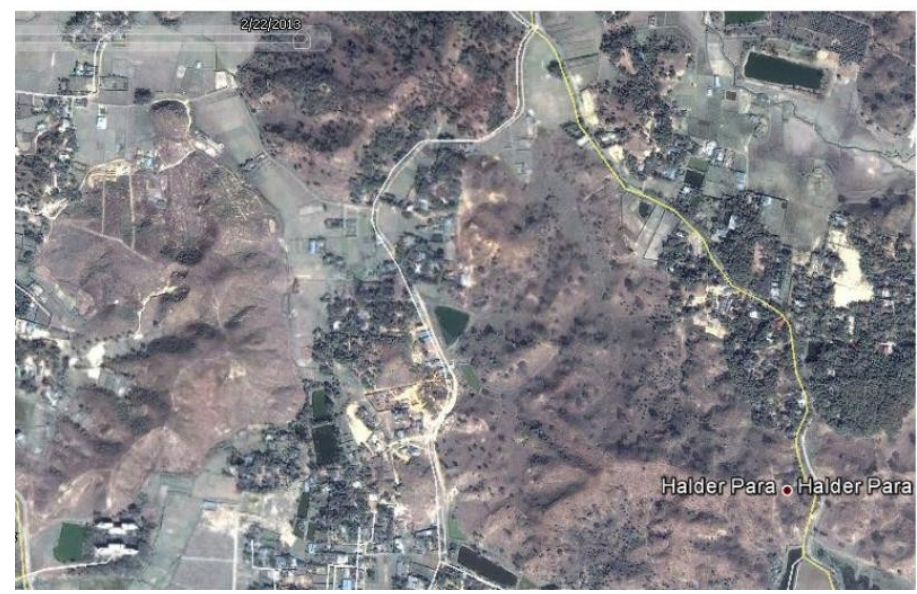

Figure 2 Current Condition after massive hill cutting

\section{Public perception about Hill cutting of People Living on Hill areas:}

We collected this public perception from Pashcim Pirmahalla area where currently a major hillocks cutting is going on for construction work of Sylhet International Stadium. These data are gathered from face to face interview of 20 peoples living on the hills. The area is full of small hillocks and some parts are nearly Inaccessible. So we took 20 interviews and these interview data is enough to get picture of public perception about hill cutting of this area. 

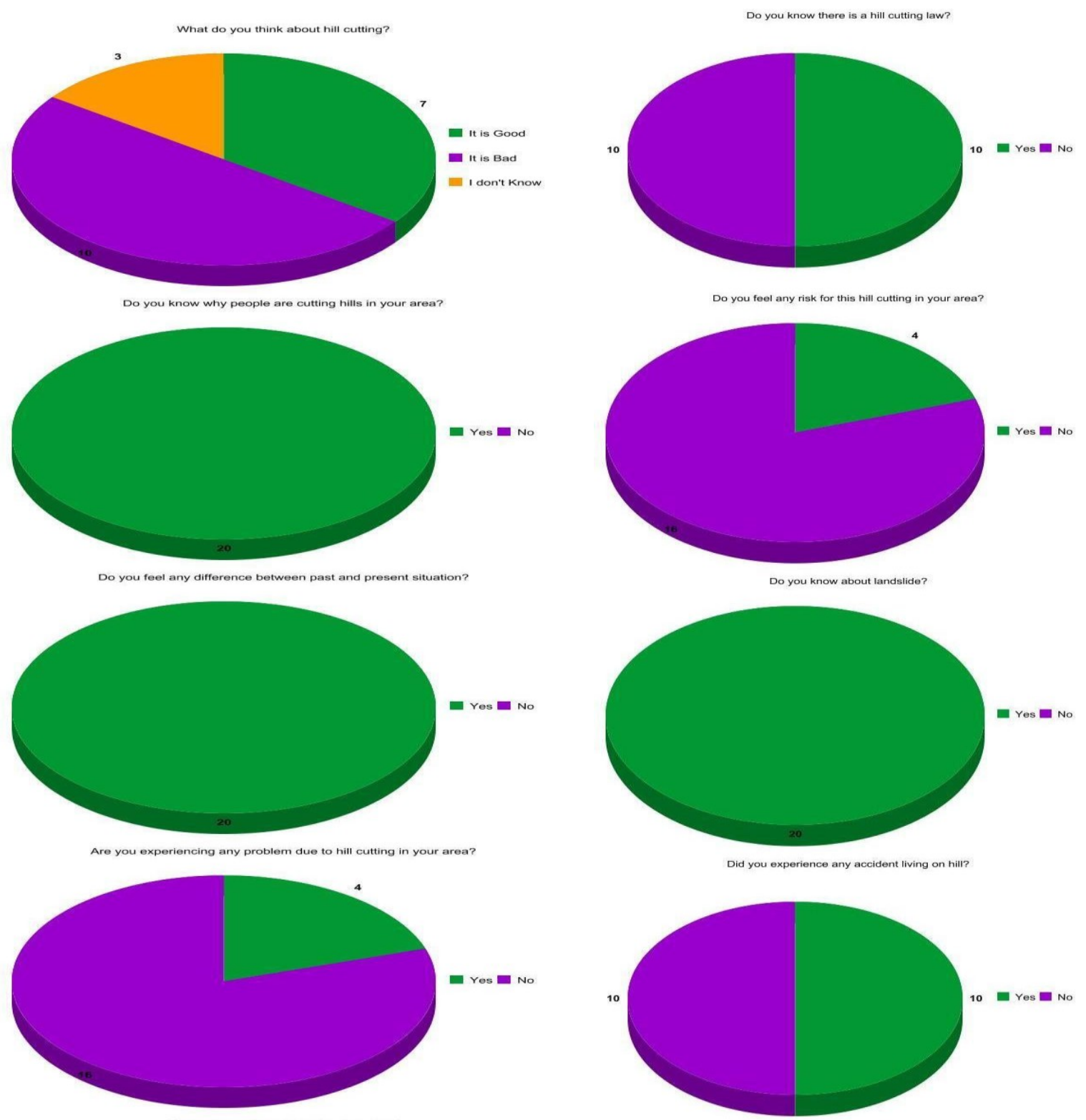

Perception of People buying Plots from Housing companies in hilly areas:

These data are also collected from face to face interview. But this time we take interview of people buying plots from hoiusing companies in hilly areas. These housing companies are largely responsible for destruction of hills and hillocks. According to DoE among 57 real estate companies listed by Sylhet Apartment and Real Estate Groups only one has clearance certificate from DoE. According to Bangladesh Environmental Lawyers' Association (BELA) none of the real estate companies was running their activities in Sylhet in a legal way. BELA divisional office statistics says that there were 300 hillocks in the city and its adjoining area but 70 percent of them have been removed in the past two decades by the housing companies. [8]

We asked 20 person did they check DoE clearance certificate of housing companies from which they bought plots. All of them said that theydid not. This indicates that most of the people buying plots from housing companies in hilly areas are unaware about hill cutting and related environmental pollution.

\section{The Main Causes of Hills and Hillocks Cutting:}

In a poverty stricken country like Bangladesh, the main reason for hill cutting is to search for new agricultural land or residential areas to fed or accommodate the country's fastest growing population. [9] .In our study area, unplanned Urbanization is the main cause behind hill cutting but there are some other potential causes. In site 01 of our study area initially hill cutting started for land filling purpose, then it begun to take land for settlement, finally now this area is experiencing major hill cutting due to construction work of Sylhet International stadium. In site-2, hill cutting started for construction of a non government educational institution (Scholarshome School and college) and a government hospital (National Heart Foundation, Sylhet). In site 3-1 
and 3-2 hill cutting is mainly going on for activities of housing companies. The causes of hill cutting in these areas can be shown by this flow chart:

Picture: Causes of hill cutting in West Pir Mahalla, Tv Gate and Halder Para
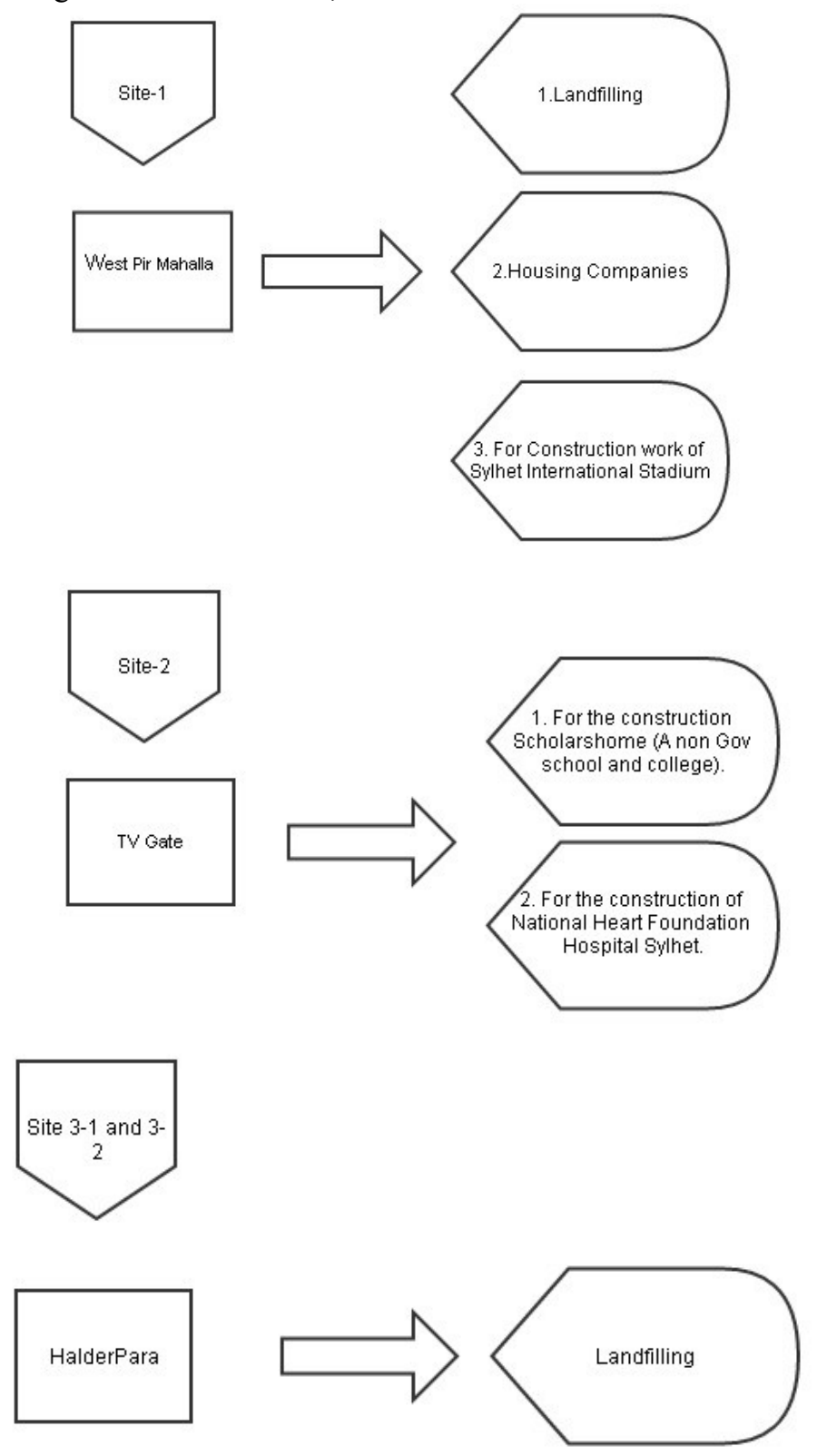

\section{Recommendation and Conclusion}

From this study we found that hills and hillocks cutting is increasing day by day in Sylhet city and most of the people are not that much aware about environmental impact of hill cutting. There is a law in Bangladesh government for stopping illegal hill cutting but housing companies on Sylhet city are not paying heed to this. Government should strictly impose this law and should punish who are breaking the law and destroying hills. Also awareness raising program about hill cutting's environmental impact is very much necessary.

\section{Acknowledgement}

Special thanks to the people participated in our survey. 


\section{References:}

[1] SCC: Official information (unpublished),Sylhet City Corporation, Sylhet, Bangladesh. (2010)

[2] Bangladesh National Building Code (BNBC), "Bangladesh National Building Code", 1993.

[3] M A Ansary \& M. Sharfuddin, “Earthquake Hazards scenario in Greater Sylhet Region” proc. H \& H 2000 conference ,Dhaka and Exter, 238.

[4] Bangladesh Meteorological Department, Dhaka, Bangladesh.

[5] Amanullah Bin Mahmood and Mamunul H. Khan, "Landslide Vulnerability of Bangladesh Hills and Sustainable Management Options: A Case Study of 2007 Landslide in Chittagong City". International Seminar Management and Mitigation of Water Induced Disaster 21-22 April 2008 Kathmundu, Nepal.

[6] Md. Sirajul Islam, 2G. M. Jahid Hasan and 3Md. Aktarul Islam Chowdhury "Destroying hills in the northeastern part of Bangladesh: A qualitative assessment of extent of the problem and its probable impact" Int. J. Environ. Sci. Tech, Winter 2006, Vol. 2, No. 4, pp. 301-308

[7] Barrister M. Omar Bin Harun Khan, Cutting of hills: Lack of law or lack of law enforcement?, Law and Our rights , Issue No: 27 July 7, 2007, The Daily Star.

[8] Md. Sirajul Islam, 2G. M. Jahid Hasan and 3Md. Aktarul Islam Chowdhury "Destroying hills in the northeastern part of Bangladesh: A qualitative assessment of extent of the problem and its probable impact" Int. J. Environ. Sci. Tech, Winter 2006, Vol. 2, No. 4, pp. 301-308 